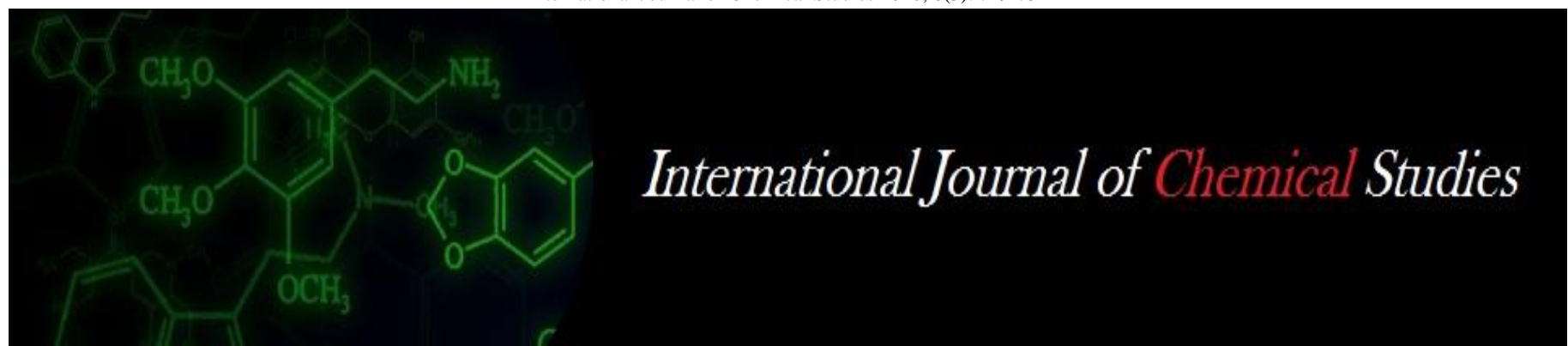

P-ISSN: 2349-8528

E-ISSN: 2321-4902

www.chemijournal.com

IJCS 2020; 8(3): 749-752

(C) 2020 IJCS

Received: 22-03-2020

Accepted: 24-04-2020

Karanje SV

Agricultural Development Trust,

Baramati, Maharashtra, India

Patil PR

Agricultural Development Trust,

Baramati, Maharashtra, India

Syed SA

Agricultural Development Trust,

Baramati, Maharashtra, India

Karpe AH

Agricultural Development Trust, Baramati, Maharashtra, India

Gharge PV

Agricultural Development Trust, Baramati, Maharashtra, India

Corresponding Author:

Patil PR

Agricultural Development Trust,

Baramati, Maharashtra, India

\section{Performance of multinutrient fertilizer stress-free (Zinc, manganese, phosphorus and nitrogen) on yield and yield contributing traits in soybean (Glycine max) against herbicide stress}

\author{
Karanje SV, Patil PR, Syed SA, Karpe AH and Gharge PV
}

DOI: https://doi.org/10.22271/chemi.2020.v8.i3i.9294

\begin{abstract}
The experiment was conducted at Agricultural development Trust, Baramati during kharif 2016, 2017 and 2018 to study the effect of Stress-Free with Imezethapyr herbicide on Soybean. Imezethapyr (Pursuit) is reccomended post-emergence herbicide for soybean, however it has been seen that Soybean crop is under physiological stress when it is sprayed with post emergence herbicide like Imezethapyr. This resulted in stunted growth for some period which resulted in less branching, less no. of pods and ultimately less yield. Results reveled that Application of Stress-Free @ $3 \mathrm{ml} / \mathrm{lit}$ and $3.5 \mathrm{ml} / \mathrm{lit}$ has more or less same results. Hence, we are recommending to use Stress-Free @ 3ml/lit as a Foliar application along with weedicide (Imezethapyr) for avoiding physiological stress due to herbicide application.
\end{abstract}

Keywords: Soybean, imezethapyr, stress free, pursuit

\section{Introduction}

Soybean has an important place in world's oilseed cultivation scenario, due to its high productivity, profitability and vital contribution towards maintaining soil fertility. The crop also has a prominent place as the world's most important seed legume, which contributes $25 \%$ to the global vegetable oil production, about two thirds of the world's protein concentrate for livestock feeding and is a valuable ingredient in formulated feeds for poultry and fish. Soybean contributes significantly to the Indian edible oil pool. Presently soybean contributes $43 \%$ to the total oilseeds and $25 \%$ to the total oil production in the country. Currently, India ranks fourth in respect to production of soybean in the world. Production of soybean in India is dominated by Maharashtra and Madhya Pradesh which contribute 89 percent of the total production.

Since the poor weed control is the major factor to reduce yield in soybean to the major extent up to $80 \%$, further mechanical weed control is not feasible and enable in timely weed control so far. Due to frequent rains, work load of farmer or unavailability of labour and increasing labour cost weed control with herbicide is becoming popular one such selective herbicide imezethapyr is widely used. however farmers have observed plant strees after application of this post emergent herbicide on soybean.

Application of product Stress free along with post emergence herbicide claims to keep the soybean crop free from physiological stress due to herbicide application. Hence a field experiment was conducted to study the actual dose of Stress free in combination with the herbicide.

\section{Material and methods}

The experiment was conducted at Agricultural development Trust, Baramati during kharif 2016, and repeated in year 2017 and 2018 to get pooled data. Experiment was conducted in Randomized Block Design with 5 replications. Five treatments given were, T1- control (Hand weeding), T2- Only Weedicide (Imezethapyr), T3- Stress-Free @ $2.5 \mathrm{ml} / \mathrm{lit}+$ Imezethapyr, T4-Stress-Free @ 3 ml/lit + Imezethapyr, T5- Stress-Free @ 3.5 ml/lit + Imezethapyr. 
Details of Product Stress free used for study are (Zinc - $4.2 \%$, Manganese- $4.0 \%$, Phosphorus- $12.0 \%$, Nitrogen-1.2\%, Filler$78 \%$ ). Plot size selected for study was Gross- $6.3 \mathrm{~m} \times 4.80 \mathrm{~m}$ and Net- $6.0 \mathrm{~m} \times 3.60 \mathrm{~m}$. Soil type in the experimental area is Medium Black Soil. Irrigation was given as and when required. Reccomended Fertilizer dose was given to soybean 50:75:45 N, $\mathrm{P}_{2} \mathrm{O}_{5}$ and $\mathrm{K}_{2} \mathrm{O} \mathrm{kg} / \mathrm{ha}$ ). Popular Soybean variety (JS-335) was selected for the experiment. Product was delived to soybean as foliar application 20 days after germination. All observation on growth and yield parameters of soybean like Plant height $(\mathrm{cm})$ before and after spray, Primary Branching per plant, Number of secondary roots per plant, Number of Nodules, Number of Pods per plant Number of seeds per Pod, Weight of 100 seeds, Soybean yield (q/ha).

\section{Results and Discussion}

Effect of treatments on growth characteristics of soybean

Plant Height before stress free application: The pooled data revealed that significant difference was recorded over the control for plant height due to application of Stress-Free on Soybean. Before Stress-Free application plant height of Soybean were non-significant among all the treatments (Table $-1)$.

Table 1: Effect of different treatments of Stress Free on Growth characteristics of Soybean. (Pooled data)

\begin{tabular}{|c|c|c|c|c|c|}
\hline Treatment & $\begin{array}{c}\text { Plant height }(\mathrm{cm}) \\
\text { before spray }\end{array}$ & $\begin{array}{c}\text { Plant height } \\
\text { (cm) after spray }\end{array}$ & \begin{tabular}{|c|} 
Number of \\
primary branches
\end{tabular} & \begin{tabular}{|c|} 
Number of \\
secondary roots
\end{tabular} & \begin{tabular}{|c|} 
Number of \\
nodules per plant
\end{tabular} \\
\hline T1-Control Hand weeding & 12.00 & 15.57 & 7.00 & $32.00 \mathrm{a}$ & $54.33 \mathrm{~b}$ \\
\hline T2- Only Weedicide (Imezethapyr) & 12.13 & 13.37 & 5.00 & 21.33 & 45.00 \\
\hline T3-Stress-Free @ 2.5 ml/lit + Imezethapyr & 12.53 & 14.93 & 6.67 & 25.33 & 51.00 \\
\hline T4 Stress-Free @ 3 ml/lit + Imezethapyr & 12.50 & $16.83 \mathrm{~b}$ & $7.67 \mathrm{a}$ & $32.00 \mathrm{a}$ & $55.67 \mathrm{a}$ \\
\hline T5 Stress-Free@ @ 3.5 ml/lit + Imezethapyr. & 12.07 & $16.93 \mathrm{a}$ & 7.33 & $31.67 \mathrm{~b}$ & $55.67 \mathrm{a}$ \\
\hline $\mathrm{CD}$ at $5 \%$ & 1 & 1.32 & 0.99 & 3.03 & 3.73 \\
\hline $\mathrm{CV}$ & 6.44 & 6.69 & 11.47 & 8.39 & 5.59 \\
\hline
\end{tabular}

Plant Height after stress free application: After application of Stress-Free with weedicide (Imezethapyr), data recorded showed that there was significant difference in plant height. The rate of increase in height was rapid in T5 (Table 1). Stress-Free application@ $3.5 \mathrm{ml} /$ lit registered significantly higher plant height $(16.93 \mathrm{~cm})$ over T1 $(15.57 \mathrm{~cm})$, T2 $(13.37 \mathrm{~cm})$ and $\mathrm{T} 3(14.93 \mathrm{~cm})$ but found at par with $\mathrm{T} 4$ $(16.83 \mathrm{~cm})$. Only weedicide (Imezethapyr) application (T2) resulted in lowest plant height. Application of Stress Free with weedicide (Imezethapyr) resulted in an increase in the plant height over T2 i.e. only weedicide (Imezethapyr). It is also observed that in conventional method of removing the weeds (T1) plant growth is not hampered which is observed in chemical method of weed control.

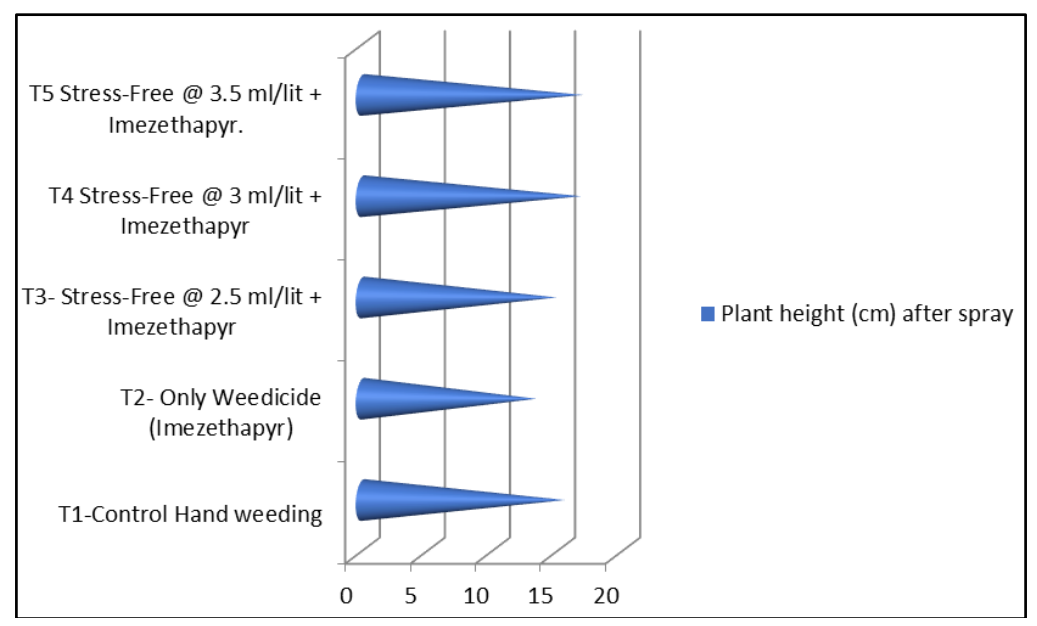

Fig 1: Plant height $(\mathrm{cm})$ after spray

Primary Branches per plant: The number of branches revealed significant difference due to application of StressFree (Table 1). The rate of increase in primary branches per plant was significantly higher in T4 i.e. weedicide (Imezethapyr) + Stress Free $3 \mathrm{ml} / \mathrm{lit}$ (7.67) over the treatments T2 i.e. only weedicide (Imezethapyr) (5), T3 (6.67) and was at par with T5 (7.33). The only weedicide (Imezethapyr) application i.e. T2 gave the lowest number of branches per plant.

Number of Secondary roots: Numbers of secondary roots per plant was significantly influenced due to application of Stress-Free (Table 1). The only weedicide (Imezethapyr) treatment $\mathrm{T} 2$ recorded significantly lower number of secondary roots. Less number of Secondary roots in only weedicide (Imezethapyr) treatment might be due to stress by chemical application. Data obtained from the table revealed that T4 Stress Free application @ $3 \mathrm{ml} /$ lit + weedicide (Imezethapyr) has shown more number of secondary roots per plant which is statistically at par with T5 i.e. stress free @ 3.5 $\mathrm{ml} / \mathrm{lit}$ and T1 i.e. conventional method. Application of Stress Free has having positive impact on number of secondary roots per plant. The application of Stress-Free resulted into the increased number of secondary roots per plant.

Number of Nodules per plant: It has been observed from the data that T2 (only application of weedicide (Imezethapyr)) for weed control has negative impact on number of root nodules per plant (Table 1). Data revealed that the treatments having combination of Weedicide (Imezethapyr) and Stress free 
showed good number of $\mathrm{N}$ fixing nodules per plant which were at par with the conventional method of weed control. Numbers of $\mathrm{N}$ fixing nodules were statistically high in T4, T5 and were at par with $\mathrm{T} 1$.

Effect of treatments on yield and yield contributing characters

Number of pods per plant: Number of pods per plant data revealed significant difference with Stress-Free application (Table 2, Graph 1). The conventional method i.e. T1 recorded as highest number of pods (74) over the T2 i.e. only weedicide (Imezethapyr) (59.2) and T3 @ $2.5 \mathrm{ml} / \mathrm{lit}$ was recorded as (67.47), but it was at par with T4 (73.53) and T5 (73.8). The number of pods per plant which is a major component in yield was found at par in T1, T4 \& T5 treatments. Treatment in which only weedicide (Imezethapyr) is applied recorded lowest number of pods per plant. Highest number of pods per plant has been recorded in T1 i.e. conventional method followed by T5, T4 and T3.

Number of Seeds per pod: Number of seeds per pod was not significantly influenced by any of the treatments (Table 2). No. of seeds per plant were found to be the same in each of the treatments.

Table 2: Effect of different treatments of Stress Free on Yield and yield contributing characters (Pooled data)

\begin{tabular}{|c|c|c|c|c|}
\hline Treatment & Number of pods per plant & No. of Seeds per pod & Weight of 100 seeds & Yield (q/ha) \\
\hline T1-control Hand weeding & 74.00 & 3.00 & $12.97 \mathrm{~b}$ & $19.83 \mathrm{~b}$ \\
\hline T2- Only Weedicide (Imezethapyr) & 59.20 & 3.00 & 12.17 & 15.80 \\
\hline T3 -Stress-Free @ 2.5 ml/lit + Imezethapyr & 67.47 & 3.00 & 12.77 & $18.53 \mathrm{~b}$ \\
\hline T4 Stress-Free @ 3 ml/lit + Imezethapyr & 73.53 & 3.00 & $13.37 \mathrm{~b}$ & $20.57 \mathrm{~b}$ \\
\hline T5 Stress-Free @ 3.5 ml/lit + Imezethapyr. & 73.80 & 3.00 & $13.40 \mathrm{a}$ & $20.67 \mathrm{a}$ \\
\hline CD & 7.57 & 0.53 & 0.57 & 2.31 \\
\hline CV & 8.55 & 12.92 & 3.44 & 9.52 \\
\hline
\end{tabular}

Weight of 100 seeds: The 100 seed weight data revealed significant difference over only weedicide (Imezethapyr) (Table 2). The Stress-Free foliar application @ 3.5ml/lit (T5) with weedicide (Imezethapyr) recorded higher seed weight (13.4g) over the T2i.e. only weedicide (Imezethapyr) (12.17g) and T3 (12.77g) but found at par with T1 (12.97g), and T4 (13.37g).

Yield (q/ha): The Soybean yield was significantly influenced due to Stress-Free application (Table 2, Graph 1). The Stress-
Free application @ $3.5 \mathrm{ml} / \mathrm{lit}$ (T5) recorded significance (20.67q/ha) over the T2i.e. only weedicide (Imezethapyr) (15.8 q/ha) but found at par with T1(19.83 q/ha), T3(18.53 $\mathrm{q} / \mathrm{ha}$ ) and T4 (20.57 q/ha). The Stress-Free revealed positive impact on growth and yield parameters were ultimately resulted into higher yield on Soybean. The only weedicide (Imezethapyr) application revealed lowest yield compare to conventional method and Stress-Free.

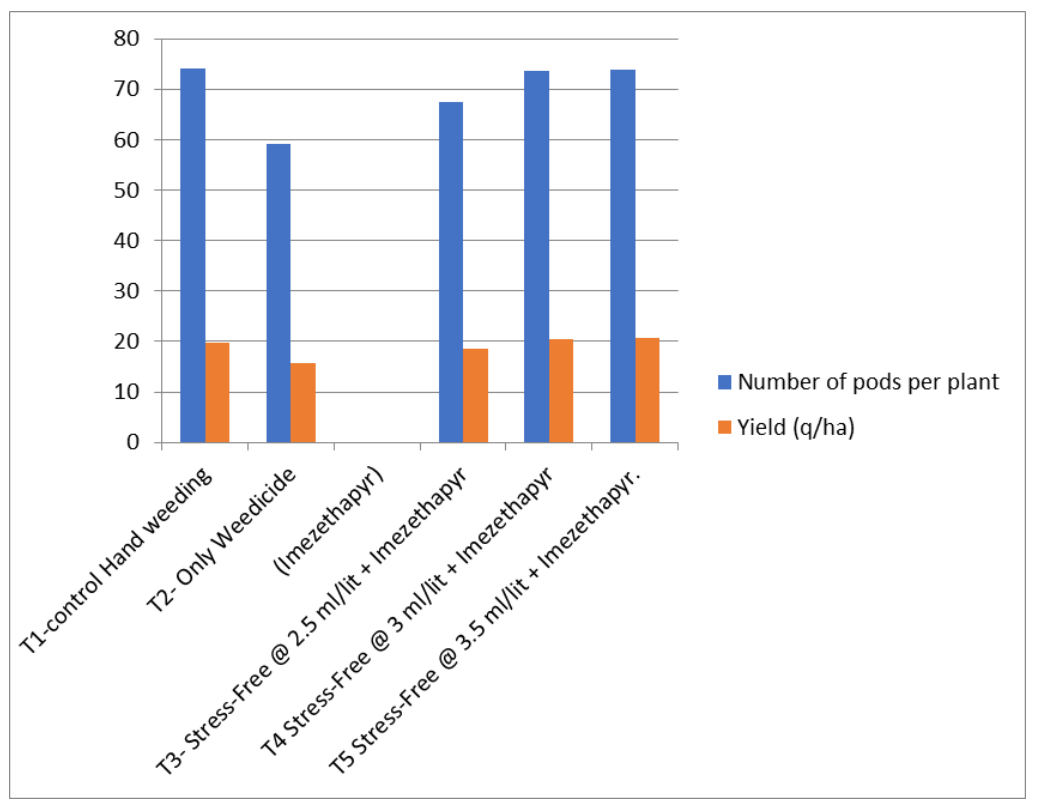

Graphs 1: Effect of different treatments of Stress Free on Number of pods per plant and Yield and characters.(Pooled data)

\section{Conclusion}

The application of Stress-Free application along with Weedicide (Imezethapyr) had favorable influence on growth and yield Contributing parameters viz. Plant height, Number of primary branches, Numbers of secondary roots, Number of nodules, Number of pods per plant and Test weight. Application of Stress-Free revealed significant influence on yield contributing characters of Soybean.
Application of Stress-Free @ $3 \mathrm{ml} / \mathrm{lit}$ and $3.5 \mathrm{ml} / \mathrm{lit}$ has more or less same results. Hence, we are recommending to use Stress-Free@3ml/lit as a Foliar application along with weedicide (Imezethapyr) for avoiding physiological stress due to herbicide application.

\section{References}

1. Raundal PU, Patil VU. Integrated Weed Management in Soybean (Glycine $\max$ L.). International Journal of 
Scientific Research in Science and Technology. 2017; 3(8):50-54.

2. Patel BD, Khedkar HP, Patel RB, Shete BT. Bioefficacy of some selective post-emergence herbicides in kharif soybean. Research on Crops. 2011; 12(2):405-408.

3. Sangeetha C, Chinnusamy C, Prabhakaran NK. Early post-emergence herbicides for weed control in soybean Indian J Weed Sci. 2012; 45(2):140- 142.

4. Smita P, Kubde KJ, Sujata Bankar. Effect of Chemical Weed Control on Weed Parameters, Growth, Yield Attributes, Yield and Economics in Soybean (Glycine max). American-Eurasian J Agric. \& Environ. Sci., 2014; 14(8):698-701.

5. Thakur VS. Effect of time of application and concentration of Imazethapyr on weed control in soybean. M.Sc. thesis (Unpub.) Dr. PDKV, Akola. 2008, 67. 